\title{
South Korean Elementary Teachers' Belief Structures in Teaching Mathematics
}

\author{
Rina Kim (Corresponding author) \\ Curriculum and Instruction, Boston College \\ 140 Commonwealth Avenue, Chestnuthill, MA 02467, U.S.A. \\ Tel: 1-617-962-9600Ｅ-mail: rina@bc.edu
}

Received: July 1, 2014 Accepted: July 15, $2014 \quad$ Published: August 6, 2014

doi:10.5296/ire.v2i2.6075 URL: http://dx.doi.org/10.5296/ire.v2i2.6075

\begin{abstract}
This study examines South Korean elementary teachers' belief structures in the application of their knowledge in mathematics instruction based on the assumption that beliefs play the role of filters when teachers apply their knowledge. From the statistical analysis of the survey data, this study reveals that there are some dominant components in South Korean elementary teachers' belief structures. In addition, some belief components might be affected by a teacher's gender and academic degrees. The findings include representative illustrations of South Korean elementary teachers' belief structures in building students' mathematics ideas, addressing students' misconceptions, engaging students in mathematics learning, and promoting students' thinking about mathematics.
\end{abstract}

Keywords: beliefs, belief structures in teaching mathematics, elementary teacher, teacher education program, educational policy

\section{Introduction}

Recent studies confirm that teachers' beliefs affect their teaching practices, such as the way they interact with students and organize classroom activities (Philipp, 2007; Torff, 2005). "Beliefs are personal, stable, and often exist in a level beyond the individual's immediate control or knowledge" (Cross, 2009, p. 326). Beliefs are considered to be strong predictors of human behaviors because they provide grounds for how a teacher frames problems and tasks in order to make a proper decision on how to instruct students (Rimm-Kaufman \& Sawyer, 2004; Torff \&Warburton, 2005). In this regard, teachers' beliefs regarding how they conceptualize instructions should be investigated in order to improve the quality of instruction, as their beliefs have a direct impact on their teaching practices in a classroom (Wilson \& Cooney, 2002). 
In the same vein, researchers in the mathematics education field emphasis the role of teachers' beliefs in the mathematics classroom based on the assumption that teachers' perceptions of teaching practices may affect students' learning in mathematics (e.g., Beuhl, Alexander \& Murphy, 2002; Cooney, 2003). For example, if a teacher has a traditional view of mathematics, such as mathematics may consist of facts or skills, she or he tends to provide teacher-directed instructions focusing on explaining mathematical concepts rather than supporting students to construct knowledge (Linblom-Yalanne, Trigwell, Nevgi \& Ashwin, 2006). Thus, to understand and to address teachers' beliefs is significant for enhancing students' learning in mathematics.

It is not easy to understand teachers' beliefs for teaching mathematics, although diverse studies have defined and investigated teachers' beliefs in various ways (e.g., the nature of mathematics, beliefs about mathematics teaching, and beliefs about students' learning; see Cooney, 2003; Cooney, Shealy \& Arvold, 1998; Ernest, 1988; Thompson, 1992); the results of the current studies are limited to specific case studies (Haser \& Dogan, 2009), and there is a lack of understanding of types of beliefs teachers have (Cross, 2009). In particular, more research about how teachers use their knowledge in a mathematics clasisroom needs to be conducted, which remains underspecified due to its intricacy (An, Kulm \& Wu, 2002).

Leatham (2006) claimed that constructing coherent models of teachers' belief systems should be the priority of teacher belief research. Stronger beliefs are held in more central locations within the belief system (Haser \& Dogan, 2012). Understanding teachers' beliefs about mathematics instruction is significant; beliefs may serve as both an affordance in the development of teachers' productive disposition (Kilpatrick, Swarfford \& Findell, 2011) and as barriers against learning or development (Drageset, 2010) because beliefs are seen as more difficult to change than emotions and attitudes (Philipp, 2007).

Toward that end, we investigate South Korean elementary teachers' belief structures in teaching mathematics in this study. We explore what kinds of components of knowledge for teaching mathematics elementary teachers consider viable and want to apply as a priority for their mathematics instruction by surveying 317 South Korean elementary teachers.

\section{Conceptual Framework}

Pajares (1992) claimed that beliefs act as filters between teachers' knowledge and their instruction. Beliefs can be held with different degrees of strengths (Cooney et al., 1998); some beliefs are held more strongly than others are (Green, 1998). Centrally held beliefs have a greater impact on teachers' instructions than those that are not (Goldin, Rosken \& Torner, 2009). According to Drageset (2010),

some teachers might state that reasoning and argumentation are the most important aspects of mathematics, and a result may be that their focus strengthens their own learning of reasoning and argumentation in mathematics because they spend more time on these aspects. On the other hand, this view may result in less focus on the repeated practice needed for the teachers to have fluency in methods and rules in mathematics. (p. 31) 
In this respect, An et al. (2002) claimed that the interconnected form of beliefs and knowledge may play a significant role in mathematics instructions, elaborating that knowledge for teaching mathematics is "[knowledge for] effective teaching includes three components, knowledge of content, knowledge of curriculum and knowledge of teaching" (p. 147). This is based on Shulman's (1987) argument that "to be a teacher requires extensive and highly organized bodies of knowledge" (p. 47). In particular, An et al. suggested that there are four aspects of mathematics instruction that are affected by the relationship between knowledge and beliefs: to address students' misconceptions, to engage students in mathematics learning, to build on students' mathematical ideas, and to promote students' thinking about mathematics. The four categories of teaching include the notion of teaching with understanding, which is defined as essential constituents for effective teaching by Carpenter and Lehrer (1999). An et al. also proposed that these four categories include essential components, which are shown in Table 1.

Table 1. Four Categories of Knowledge and Their Essential Components (Adapted from An, Kulm, \& Wu, 2002).

\begin{tabular}{ll}
\hline \multicolumn{1}{c}{ Categories } & \multicolumn{1}{c}{ Essential Components } \\
\hline Building on students' mathematics & 1. Connect to prior knowledge \\
ideas & 2. Use concept or definition \\
& 3. Connect to concrete model \\
& 4. Use rule and procedures \\
\hline Addressing students' & 1. Address students' misconceptions \\
misconception & 2. Use questions or tasks to correct misconceptions \\
& 3. Use rule and procedure \\
& 4. Draw pictures or table \\
& 5. Connect to concrete model \\
\hline Engaging students in mathematics & 1. Manipulative activity \\
learning & 2. Connect to concrete model \\
& 3. Use representations \\
& 4. Give example \\
& 5. Connection to prior knowledge \\
\hline 1. Provide activities to focus on students' thinking \\
2. Use questions or tasks to help students' progress in their ideas \\
3romoting students' thinking abouthematics
\end{tabular}

Teachers' use of essential components in each category might differ according to teachers' beliefs regarding how they perceive the importance of each component in students' learning (An et al., 2002). The four categories and subsequent components were used with our understanding of teachers' beliefs and to develop items for the survey in this study. 


\section{Methods}

Conducting a survey helped to develop a broader perspective about elementary teachers' belief structures because the survey method is useful when the purpose of the study is to quantitatively describe specific aspects of a given population (Kraemer, 1991). If the survey collects data based on a representative sample, the data can be generalizable to a population (Kelley, Clark, Brown, \& Sitzia, 2003). We surveyed 317 randomly selected South Korean elementary teachers in order to ensure validity and to generalize findings.

\subsection{Participants}

The target population of the study is South Korean elementary teachers. We chose participants who work in Seoul because of its geographical accessibility. The location of the elementary school in which a participant is working may not be significant because teachers' quality and distribution are highly controlled by the Ministry of Education of South Korea. Also, by law, elementary teachers are required to change schools in a province every 5 years and change teaching grade levels each school year.

According to a survey from the Ministry of Education of South Korea (2012), there are 181,435 elementary teachers in South Korea; among them, 29,762 work in Seoul; from this group, we randomly selected 1,109 elementary teachers for this study. Among them, 317 elementary teachers participated in the survey. Descriptive statistics about the obtained sample are provided in Table 2.

Table 2. Demographic Information of the Participants

\begin{tabular}{|c|c|c|c|c|}
\hline & & \multicolumn{2}{|c|}{ Gender } & \multirow[t]{2}{*}{ Total Number } \\
\hline & & Male (n) & Female (n) & \\
\hline \multirow{6}{*}{$\begin{array}{c}\text { Teaching } \\
\text { Experience }\end{array}$} & $0-5$ years & 20 & 87 & 107 \\
\hline & $6-10$ years & 15 & 56 & 71 \\
\hline & 11-15 years & 5 & 40 & 45 \\
\hline & 16-20 years & 3 & 14 & 17 \\
\hline & 21 years -more & 11 & 61 & 72 \\
\hline & Total & 54 & 258 & 312 \\
\hline \multirow{3}{*}{$\begin{array}{c}\text { *Teacher } \\
\text { Certification }\end{array}$} & $1^{\text {st }}$ level & 34 & 164 & 199 \\
\hline & $2^{\text {nd }}$ level & 17 & 88 & 105 \\
\hline & Total & 51 & 263 & 304 \\
\hline \multirow{4}{*}{ Degree } & Bachelor & 45 & 221 & 266 \\
\hline & Master & 6 & 34 & 40 \\
\hline & Doctor & 1 & 0 & 1 \\
\hline & Total & 52 & 255 & 307 \\
\hline
\end{tabular}

* Note. When completing the bachelor's degree, graduates receive Teacher Certification at the second level and only receive the first level after teaching 3 to 5 years and completing 180 hours of professional development courses in a teacher preparation program. 
Although 317 South Korean elementary teachers participated in this survey, the participants were given the option to skip questions they did not want to answer. Therefore, the total number of participants may differ among sections, which present different demographic information.

\subsection{Participants}

The quality and the distribution of elementary teachers are highly controlled by the government in South Korea. For example, there are only 13 universities that offer preservice education programs for those interested in becoming elementary school teachers. After graduation, preservice teachers acquire the teacher certification level 2; they are then qualified to work as a teacher in a private elementary school. In order to work in a public school, preservice teachers are required to pass the national teacher recruitment examination provided by one of the states in which they apply. After passing the exam, the state's office of education places the teacher at an elementary school. According to the Ministry of Education of South Korea (2012), there are 5,895 elementary schools in the country. Among them, only 76 schools $(1.3 \%)$ are private schools.

According to the National Mathematics Curriculum of South Korea (2009), elementary teachers in both public and private schools are required to teach mathematics. The National Mathematics Curriculum of South Korea provides mathematical topics that students should learn in each grade, the instructional goal of every topic, and how teachers should assess students' work. Based on the National Basic Curriculum of South Korea, the government develops the mathematics textbooks and teachers' guidebook and provides them to all elementary students and teachers in South Korea for free. The teachers' guidebook contains short lesson plans and materials for teaching.

\subsection{Data Sources}

In order to investigate South Korean elementary teachers' belief structures regarding their use of knowledge, we developed a survey instrument from the conceptual framework of this study. The instrument was translated and adapted into Korean by the authors, and tests to ensure validity were conducted. One author of this study participated in translating the survey items from English to Korean. This author is a native Korean speaker who is also fluent in English and has 10 years of teaching experience in South Korea. The reliability of the survey items is 0.8 based on test-retest assessment with 40 South Korean elementary teachers. Ten specialists who work in South Korean elementary schools validated the terms that were used for the survey items. The teachers have master's degrees in mathematics education and the experience to develop the National Mathematics Curriculum and the national textbook for the elementary level.

\subsection{Procedure}

We developed a web-based questionnaire for the survey in order to reveal South Korean elementary teachers' beliefs about knowledge for teaching mathematics. We obtained approval from the Institutional Review Board to conduct research with human subjects from Boston College. The questionnaire also included a consent form, which provided information 
about the purpose of the research, the contact name and address of the researcher, any potential benefits or harm resulting from the study, and what would happen to the information provided.

In May 2012, we obtained approval from the Ministry of Education of South Korea to conduct research with South Korean elementary teachers in Seoul. The analysis was conducted in order to ensure the validity and reliability of the survey items in May 2012. This process allowed the researchers to identify whether the respondents understood the instructions and the questions, and whether the meaning of the questions was the same for all respondents. Between June and August 2012, the link to the web-based questionnaire was sent to 1,109 elementary teachers by a school networking system in 30 elementary schools in Seoul. These 30 elementary schools were selected randomly. Participation was voluntary; there had been no previous contact between researchers and respondents. Among the 1,109 survey recipients, 317 elementary teachers participated in the survey, yielding a response rate of $29 \%$.

\subsection{Data Analysis}

Data were analyzed to examine the characteristics of the teachers in this study. Analyses of variance (ANOVA) were conducted to investigate whether the teachers were different in terms of their belief structures based on their other background information (e.g., gender, certification level). A randomized block ANOVA (RBANOVA) also was employed in order to examine the mean differences among components, which the teachers believe to be significant. According to Shavelson (1996), the RBANOVA is used to help researchers decide whether the observed differences of means between two or more groups caused by chance or by systematically. In addition, the data satisfied the following design requirements (Shavelson, 1996): the level of independent/dependent variables, assumption of normal distribution, and assumption of no outliers. The Huynh-Feldt correction was considered to satisfy the sphericity assumption. Tukey's Honestly Significant Difference (HSD) test was also employed with the Bonferroni correction to examine where differences existed. The computer statistical tool SPSS (SPSS Statistics 20) was used to analyze the data. All results were reported at $\alpha=0.05$.

\section{Results}

\subsection{Analysis Variance}

Table 3 summarizes the results of the survey. For South Korean elementary teachers' beliefs about building students' mathematics ideas, there were no significant differences among groups of teachers' mean scores based on their gender, academic degrees, certification level, or teaching experience $(p<.05)$. 
Table 3. Results of analysis of variance

\begin{tabular}{|c|c|c|c|c|c|c|}
\hline \multirow[t]{2}{*}{ Variable } & \multicolumn{5}{|c|}{$\begin{array}{l}\text { The number of teachers who respond to each component of building on } \\
\text { students' mathematics ideas. }\end{array}$} & \multirow[t]{2}{*}{ Mean (SD) $p$ value } \\
\hline & $\begin{array}{l}\text { Connect to } \\
\text { knowledge }\end{array}$ & $\begin{array}{l}\text { prior Use concept } \\
\text { definition }\end{array}$ & & rete & & \\
\hline Gender & & & & & & 0.738 \\
\hline Male & & 31 & 8 & 7 & 7 & $1.78(0.34)$ \\
\hline Female & & 113 & 27 & 78 & 37 & $1.77(0.72)$ \\
\hline \multicolumn{7}{|l|}{$\begin{array}{l}\text { Academic } \\
\text { Degrees }\end{array}$} \\
\hline Bachelor & & 107 & 31 & 71 & 38 & $2.16(1.14) 0.54$ \\
\hline Master & & 27 & 3 & 9 & 2 & $1.66(0.99)$ \\
\hline Doctor & & 1 & 0 & 0 & 0 & 1.00 \\
\hline Certification & & & & & & 0.97 \\
\hline $1^{\text {st }}$ & & 97 & 17 & 55 & 29 & $1.33(0.48)$ \\
\hline $2^{\text {nd }}$ & & 45 & 18 & 27 & 10 & $1.51(0.57)$ \\
\hline $\begin{array}{l}\text { Teaching } \\
\text { Experiences }\end{array}$ & & & & & & 0.88 \\
\hline $0-5$ years & & 45 & 20 & 31 & 10 & $2.06(1.05)$ \\
\hline $6-10$ years & & 39 & 3 & 18 & 8 & $1.93(1.15)$ \\
\hline $11-15$ years & & 27 & 4 & 10 & 6 & $1.89(1.14)$ \\
\hline $16-20$ years & & 6 & 3 & 6 & 2 & $2.24(1.09)$ \\
\hline$>21$ years & & 28 & 6 & 20 & 18 & $2.36(1.14)$ \\
\hline
\end{tabular}

Variable The number of teachers who respond to each component of addressing Mean (SD) $p$ value students' misconceptions.

\begin{tabular}{lllcr}
\hline $\begin{array}{l}\text { Address } \\
\text { students' } \\
\text { misconception }\end{array}$ & $\begin{array}{l}\text { Use questions Use rules } \\
\text { or tasks to procedure } \\
\text { correct }\end{array}$ & $\begin{array}{c}\text { and Draw } \\
\text { picture } \\
\text { misconception }\end{array}$ & $\begin{array}{c}\text { Connect } \\
\text { table }\end{array}$ & $\begin{array}{l}\text { concrete } \\
\text { model }\end{array}$
\end{tabular}

\begin{tabular}{|c|c|c|c|c|c|c|}
\hline Gender & & & & & & $0.00 *$ \\
\hline Male & 5 & 26 & 8 & 12 & 3 & $2.67(1.09)$ \\
\hline Female & 30 & 120 & 18 & 40 & 47 & $2.82(1.34)$ \\
\hline \multicolumn{7}{|l|}{$\begin{array}{l}\text { Academic } \\
\text { Degrees }\end{array}$} \\
\hline Bachelor & 28 & 118 & 20 & 40 & 42 & $2.80(1.31) 0.22$ \\
\hline Master & 7 & 17 & 4 & 8 & 5 & $2.68(1.31)$ \\
\hline Doctor & 0 & 1 & 0 & 0 & 0 & 2.00 \\
\hline Certification & & & & & & 0.88 \\
\hline $1^{\text {st }}$ & 27 & 88 & 24 & 30 & 30 & $2.75(1.29)$ \\
\hline $2^{\text {nd }}$ & 7 & 52 & 1 & 20 & 20 & $2.94(1.34)$ \\
\hline $\begin{array}{l}\text { Teaching } \\
\text { Experiences }\end{array}$ & & & & & & 0.25 \\
\hline $0-5$ years & 8 & 58 & 1 & 19 & 20 & $2.86(1.33)$ \\
\hline $6-10$ years & 5 & 39 & 7 & 12 & 6 & $2.64(1.12)$ \\
\hline $11-15$ years & 9 & 20 & 7 & 4 & 7 & $2.57(1.31)$ \\
\hline $16-20$ years & 2 & 5 & 2 & 2 & 6 & $3.29(1.53)$ \\
\hline$>21$ years & 12 & 24 & 9 & 15 & 12 & $2.88(1.31)$ \\
\hline
\end{tabular}


The number of teachers who respond to each component of engaging Mean (SD) $p$ value students in mathematics learning.

\begin{tabular}{llll}
\hline $\begin{array}{l}\text { Manipulative } \\
\text { activity }\end{array}$ & $\begin{array}{l}\text { Connect to Use } \\
\text { concrete model representations }\end{array}$ & $\begin{array}{l}\text { Give } \\
\text { examples }\end{array}$ & $\begin{array}{l}\text { Connect to } \\
\text { prior } \\
\text { knowledge }\end{array}$
\end{tabular}

\begin{tabular}{lrrrrr}
\hline Gender & & & & 0.79 \\
Male & 15 & 6 & 7 & 22 & $42.89(1.39)$ \\
Female & 91 & 47 & 7 & 86 & $222.61(1.47)$ \\
\hline
\end{tabular}

\begin{tabular}{|c|c|c|c|c|c|}
\hline \multicolumn{6}{|l|}{$\begin{array}{l}\text { Academic } \\
\text { Degrees }\end{array}$} \\
\hline Bachelor & 88 & 46 & 11 & 91 & $112.56(1.40)$ \\
\hline Master & 14 & 5 & 2 & 8 & $102.87(1.68)$ \\
\hline Doctor & 1 & 0 & 0 & 0 & 01.00 \\
\hline \multicolumn{6}{|l|}{ Certification } \\
\hline $1^{\text {st }}$ & 72 & 31 & 11 & 64 & $18 \quad 2.75(1.29$ \\
\hline $2^{\text {nd }}$ & 33 & 20 & 2 & 40 & $52.94(1.34)$ \\
\hline \multicolumn{6}{|l|}{$\begin{array}{l}\text { Teaching } \\
\text { Experiences }\end{array}$} \\
\hline $0-5$ years & 37 & 21 & 2 & 42 & $42.58(1.40)$ \\
\hline $6-10$ years & 23 & 12 & 1 & 26 & $62.71(1.48)$ \\
\hline $11-15$ years & 17 & 4 & 4 & 17 & $42.72(1.50)$ \\
\hline $16-20$ years & 7 & 2 & 2 & 2 & $32.50(1.63)$ \\
\hline$>21$ years & 23 & 14 & 5 & 21 & $92.71(1.48)$ \\
\hline
\end{tabular}

Variable The number of teachers who respond to each component of promoting Mean (SD) $p$ value students' thinking about mathematics.

\begin{tabular}{|c|c|c|c|}
\hline $\begin{array}{l}\text { Provide } \\
\text { activities } \\
\text { focus } \\
\text { students' } \\
\text { thinking }\end{array}$ & $\begin{array}{l}\text { Use questions Use estimation } \\
\text { to or tasks to help } \\
\text { on students' } \\
\text { progress in } \\
\text { their ideas. }\end{array}$ & $\begin{array}{l}\text { Draw } \\
\text { picture } \\
\text { table }\end{array}$ & $\begin{array}{l}\text { Provide } \\
\text { or opportunity } \\
\text { to think and } \\
\text { respond }\end{array}$ \\
\hline
\end{tabular}

\begin{tabular}{|c|c|c|c|c|c|c|}
\hline Gender & & & & & & 0.67 \\
\hline Male & 26 & 18 & 3 & 1 & 6 1.94(1.28) & \\
\hline Female & 124 & 89 & 10 & 10 & $211.88(1.19)$ & \\
\hline \multicolumn{7}{|l|}{$\begin{array}{l}\text { Academic } \\
\text { Degrees }\end{array}$} \\
\hline Bachelor & 118 & 91 & 8 & 10 & $201.88(1.18)$ & 0.78 \\
\hline Master & 21 & 10 & 3 & 2 & $52.02(1.38)$ & \\
\hline Doctor & 1 & 0 & 0 & 0 & 01.00 & \\
\hline Certification & & & & & & 0.27 \\
\hline $1^{\text {st }}$ & 99 & 68 & 11 & 10 & $61.84(1.15)$ & \\
\hline $2^{\text {nd }}$ & 46 & 35 & 2 & 2 & $52.02(1.33)$ & \\
\hline $\begin{array}{l}\text { Teaching } \\
\text { Experiences }\end{array}$ & & & & & & 0.06 \\
\hline $0-5$ years & 46 & 39 & 2 & 7 & $122.06(1.32)$ & \\
\hline $6-10$ years & 24 & 36 & 2 & 1 & $61.97(1.11)$ & \\
\hline $11-15$ years & 26 & 10 & 3 & 2 & $61.98(1.46)$ & \\
\hline $16-20$ years & 14 & 2 & 0 & 0 & $11.35(0.99)$ & \\
\hline$>21$ years & 41 & 20 & 6 & 2 & $21.65(0.95)$ & \\
\hline
\end{tabular}


Regarding South Korean elementary teachers' beliefs about addressing students' misconceptions, there were no significant differences among groups of teachers' mean scores based on their academics degrees, certification levels, and teaching experiences $(p<.05)$. The mean scores for the two groups based on the gender of the teachers were statistically significantly different $(p=0.005)$. For South Korean elementary teachers' beliefs about engaging students in mathematics learning, there were no significant differences among groups of teachers' mean scores based on their gender, academic degrees, certification level, and teaching experience $(p<.05)$.

For South Korean elementary teachers' beliefs about promoting students' thinking about mathematics, there were no significant differences among groups of teachers' mean scores based on their gender, certification level, and teaching experience $(p<.05)$. The mean scores for the two groups based on teachers' academic degrees were statistically significantly different $(F=2.83, p=0.025)$.

\subsection{Randomized Block Analysis of Variance}

The mean scores for the components in each category are shown in Table 3. An RBANOVA with a Huynh-Feldt correction determined that teachers reported different priorities among the components of knowledge in mathematics teaching, and the differences were statistically significant $(P<0.05)$. Post hoc tests using the Bonferroni correction revealed that some pairwise comparisons were statistically significant at $\alpha=0.05$. Table 4 contains the results of the analysis.

Table 4. Results of Randomized Block Analysis of Variance

\begin{tabular}{|c|c|c|c|c|c|c|c|}
\hline \multirow[t]{2}{*}{ Variable } & \multirow[t]{2}{*}{ (1) Component } & \multirow[t]{2}{*}{$\begin{array}{l}\text { (2) Compared } \\
\text { component }\end{array}$} & \multirow[t]{2}{*}{$\begin{array}{r}\text { Mean } \\
\text { Difference } \\
(1-2)\end{array}$} & \multirow[t]{2}{*}{$\begin{array}{l}\text { Std. } \\
\text { Error }\end{array}$} & \multirow[t]{2}{*}{ Sig. ${ }^{b}$} & \multicolumn{2}{|c|}{$\begin{array}{l}95 \% \text { Confidence } \\
\text { Interval for } \\
\text { Difference }^{\mathrm{b}}\end{array}$} \\
\hline & & & & & & $\begin{array}{l}\text { Lower } \\
\text { Bound }\end{array}$ & $\begin{array}{l}\text { Upper } \\
\text { Bound }\end{array}$ \\
\hline \multirow{6}{*}{$\begin{array}{l}\text { Building } \\
\text { students' } \\
\text { mathematics } \\
\text { ideas }\end{array}$} & \multirow{3}{*}{$\begin{array}{l}\text { Connect to prior } \\
\text { knowledge }\end{array}$} & $\begin{array}{l}\text { Use concept or } \\
\text { definition }\end{array}$ & $.352^{*}$ & .039 & $.000 *$ & .249 & .454 \\
\hline & & $\begin{array}{l}\text { Connect to } \\
\text { concrete model }\end{array}$ & $.194^{*}$ & .048 & $.000 *$ & .067 & .320 \\
\hline & & $\begin{array}{l}\text { Use rules and } \\
\text { procedures }\end{array}$ & $.326^{*}$ & .040 & $.000 *$ & .219 & .433 \\
\hline & \multirow{2}{*}{$\begin{array}{l}\text { Use concept or } \\
\text { definition }\end{array}$} & $\begin{array}{l}\text { Connect to concrete } \\
\text { model }\end{array}$ & $-.158^{*}$ & .034 & $.000 *$ & -.249 & -.067 \\
\hline & & $\begin{array}{l}\text { Use rules and } \\
\text { procedures }\end{array}$ & -.026 & .029 & 1.000 & -.102 & .051 \\
\hline & $\begin{array}{ll}\text { Connect } & \text { to } \\
\text { concrete model }\end{array}$ & $\begin{array}{l}\text { Use rules and } \\
\text { procedures }\end{array}$ & $.132^{*}$ & .036 & $.002 * *$ & .037 & .228 \\
\hline \multirow{2}{*}{$\begin{array}{l}\text { Addressing } \\
\text { students' } \\
\text { misconception }\end{array}$} & \multirow{2}{*}{$\begin{array}{l}\text { Address students' } \\
\text { misconception }\end{array}$} & $\begin{array}{l}\text { Use questions or } \\
\text { tasks to correct } \\
\text { misconception }\end{array}$ & $-.354^{*}$ & .039 & $.000 *$ & -.463 & -.245 \\
\hline & & $\begin{array}{l}\text { Use rule and } \\
\text { procedure }\end{array}$ & .032 & .025 & 1.000 & -.039 & .104 \\
\hline
\end{tabular}




\begin{tabular}{|c|c|c|c|c|c|c|c|}
\hline & & $\begin{array}{l}\text { Draw picture or } \\
\text { table }\end{array}$ & -.051 & .030 & .881 & -.136 & .034 \\
\hline & & $\begin{array}{l}\text { Connect to } \\
\text { concrete model }\end{array}$ & -.048 & .030 & 1.000 & -.133 & .036 \\
\hline & & $\begin{array}{l}\text { Use rule and } \\
\text { procedure }\end{array}$ & $.386^{*}$ & .036 & $.000 *$ & .284 & .488 \\
\hline & $\begin{array}{l}\text { Use questions or } \\
\text { tasks to correct } \\
\text { misconception }\end{array}$ & $\begin{array}{l}\text { Draw picture or } \\
\text { table }\end{array}$ & $.302^{*}$ & .042 & $.000^{*}$ & .184 & .421 \\
\hline & & $\begin{array}{l}\text { Connect to } \\
\text { concrete model }\end{array}$ & $.305^{*}$ & .042 & $.000 *$ & .187 & .423 \\
\hline & Use rule & $\begin{array}{l}\text { Draw picture or } \\
\text { table }\end{array}$ & $-.084^{*}$ & .028 & .031 & -.163 & -.004 \\
\hline & procedure & $\begin{array}{l}\text { Connect to } \\
\text { concrete model }\end{array}$ & $-.080^{*}$ & .028 & .042 & -.159 & -.002 \\
\hline & $\begin{array}{l}\text { Draw picture or } \\
\text { table }\end{array}$ & $\begin{array}{ll}\text { Connect } & \text { to } \\
\text { concrete model }\end{array}$ & .003 & .033 & 1.000 & -.089 & .096 \\
\hline \multirow{10}{*}{$\begin{array}{l}\text { Engaging } \\
\text { students } \\
\text { mathematics } \\
\text { learning }\end{array}$} & \multirow{4}{*}{$\begin{array}{l}\text { Manipulative } \\
\text { activity }\end{array}$} & $\begin{array}{l}\text { Connect to } \\
\text { concrete model }\end{array}$ & $.175^{*}$ & .040 & $.000^{*}$ & .063 & .288 \\
\hline & & $\begin{array}{l}\text { Use } \\
\text { representations }\end{array}$ & $.302^{*}$ & .031 & $.000^{*}$ & .213 & .391 \\
\hline & & Give example & -.003 & .048 & 1.000 & -.138 & .132 \\
\hline & & $\begin{array}{l}\text { Connection to } \\
\text { prior knowledge }\end{array}$ & $.263^{*}$ & .034 & $.000 *$ & .166 & .360 \\
\hline & \multirow{3}{*}{$\begin{array}{l}\text { Connect to } \\
\text { concrete model }\end{array}$} & $\begin{array}{l}\text { Use } \\
\text { representations }\end{array}$ & $.127^{*}$ & .026 & $.000 *$ & .054 & .199 \\
\hline & & Give example & $-.179^{*}$ & .040 & $.000^{*}$ & -.292 & -.066 \\
\hline & & $\begin{array}{l}\text { Connection to } \\
\text { prior knowledge }\end{array}$ & $.088^{*}$ & .028 & $.02 .3 *$ & .007 & .168 \\
\hline & \multirow{2}{*}{$\begin{array}{l}\text { Use } \\
\text { representations }\end{array}$} & Give example & $-.305^{*}$ & .031 & $.000^{*}$ & -.394 & -.216 \\
\hline & & $\begin{array}{l}\text { Connection to } \\
\text { prior knowledge }\end{array}$ & -.039 & .020 & .577 & -.097 & .019 \\
\hline & Give example & $\begin{array}{l}\text { Connection to } \\
\text { prior knowledge }\end{array}$ & $.266^{*}$ & .034 & $.000 *$ & .169 & .364 \\
\hline \multirow{7}{*}{$\begin{array}{l}\text { Promoting } \\
\text { students' } \\
\text { thinking about } \\
\text { mathematics }\end{array}$} & \multirow{4}{*}{$\begin{array}{l}\text { Provide activities } \\
\text { to focus on } \\
\text { students' thinking }\end{array}$} & $\begin{array}{l}\text { Use questions or } \\
\text { tasks to help } \\
\text { students' progress } \\
\text { in their ideas }\end{array}$ & .142 & .051 & .060 & -.003 & .287 \\
\hline & & Use estimation & $.445^{*}$ & .033 & $.000^{*}$ & .353 & .538 \\
\hline & & $\begin{array}{l}\text { Draw picture or } \\
\text { table }\end{array}$ & $.448^{*}$ & .032 & $.000 *$ & .357 & .540 \\
\hline & & $\begin{array}{l}\text { Provide } \\
\text { opportunity to } \\
\text { think and respond }\end{array}$ & $.400^{*}$ & .037 & $.000 *$ & .296 & .504 \\
\hline & \multirow{3}{*}{$\begin{array}{l}\text { Use questions or } \\
\text { tasks to help } \\
\text { students' progress } \\
\text { in their ideas }\end{array}$} & Use estimation & $.303^{*}$ & .031 & $.000^{*}$ & .216 & .391 \\
\hline & & $\begin{array}{l}\text { Draw picture or } \\
\text { table }\end{array}$ & $.306^{*}$ & .031 & $.000 *$ & .220 & .393 \\
\hline & & $\begin{array}{l}\text { Provide } \\
\text { opportunity to } \\
\text { think and respond }\end{array}$ & $.258^{*}$ & .034 & $.000 *$ & .161 & .355 \\
\hline
\end{tabular}




\begin{tabular}{llllllll} 
& & $\begin{array}{l}\text { Draw picture or } \\
\text { table }\end{array}$ & .003 & .016 & 1.000 & -.042 & .049 \\
Use estimation & $\begin{array}{l}\text { Provide } \\
\text { opportunity to } \\
\text { think and respond }\end{array}$ & -.045 & .020 & .266 & -.102 & .012 \\
\hline $\begin{array}{l}\text { Draw picture } \\
\text { table }\end{array}$ & $\begin{array}{l}\text { Provide } \\
\text { opportunity to } \\
\text { think and respond }\end{array}$ & -.048 & .020 & .161 & -.105 & .008 \\
\hline
\end{tabular}

* Note. significant at 0.01 level.

As shown in Table 4, we may see that the South Korean elementary teachers believe that related the response "connect to prior knowledge" as the most significant component for building students' mathematics ideas, and "use questions or tasks to correct misconceptions" as the most effective for addressing students' misconceptions. Although the teachers believe that manipulative activity might be the most effective in engaging students in mathematics learning, there were no statistical differences between the mean for "manipulative activity" and "give example," which ranked as the second significant component $(P<0.05)$. "Use questions or tasks to help students' progress" was considered the most significant component in promoting students' thinking about mathematics.

\section{Discussion}

There were no significant differences among groups of teachers in this study based on gender, academic degrees, certification level, and teaching experience with the exception of two categories of beliefs toward the use of knowledge: addressing students' misconceptions and engaging students in mathematics learning.

For addressing students' misconceptions, there was a significant difference between groups of teachers based on their gender of the teachers $(p<0.05)$. Both male and female teachers considered "use questions or tasks to correct misconceptions" as the most significant component as shown in Figure 1. However, female teachers believe that connecting to a concrete model is significant in correcting students' misconceptions, compared to most of the other components, while male teachers believe that it is the least significant component. Although there are not many discussions regarding the effect of teachers' gender on their use of concrete models in mathematics instruction, studies argue that female students prefer to use concrete models when they are required to solve mathematics problems than male students (e.g. Casey, Nuttall \& Pezaris, 2001; Fennema, Carpenter, Jacobs, Franke \& Levi, 1998). When considering the fact that there were not significant differences among groups of teachers based on the other variables (e.g., academic degrees), the results of data analysis may demonstrate that there might be some innate beliefs caused by gender differences, which is difficult to change despite teacher education programs or teaching experiences. 


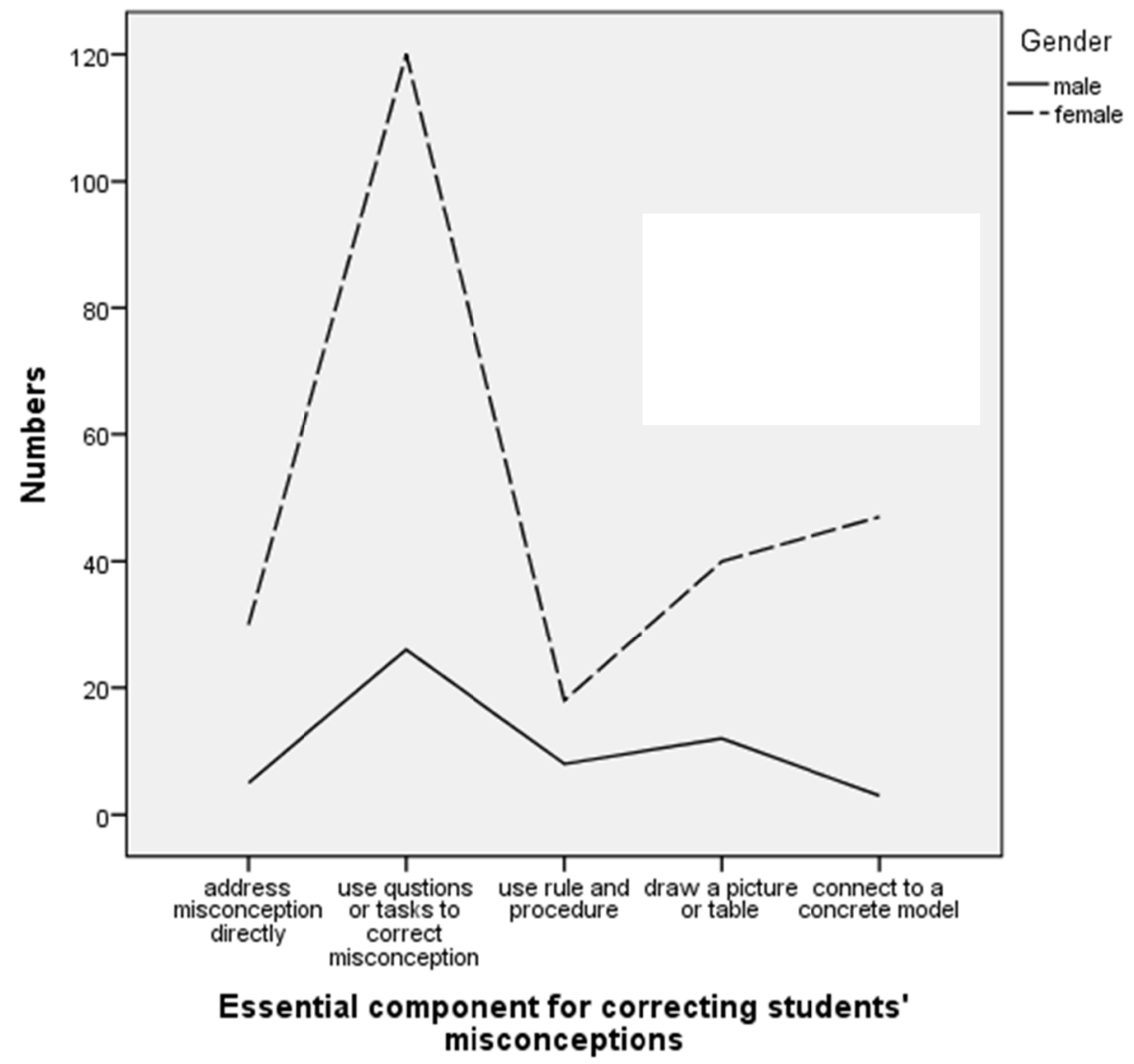

Figure 1. Line graph of essential component for correcting students' misconceptions

Regarding engaging students in mathematics learning, there were significant differences among groups of teachers according to their academic degrees; however, only one participant in this study had acquired a doctoral degree. As noted previously, small sample size might affect the interpretation of the relationship from statistical analysis. Eliminating the doctor group from the analysis resulted in a significant difference between groups of teachers regarding their beliefs toward the essential component for engaging students in mathematics learning ( $p=0.003$ ). Both groups of teachers who had bachelor's and master's degrees believed that manipulative activities and giving examples are effective ways of engaging students in mathematics learning, as shown in Figure 2. However, teachers who attained master's degrees considered the connection to prior knowledge to be one of the significant components, while teachers who had bachelor's degrees believed that it is the least significant component in engaging students' mathematics learning.

Recent studies suggest that teachers' academic degrees may affect teachers' beliefs toward mathematics education (e.g., Cross, 2009; Philipp et al., 2007). However, the relationship between teachers' knowledge and its effect on beliefs systems was vague because it was not easy to define teachers' beliefs in teaching practices due to their unstable nature, which might be related to different contexts and consciousness. The results of data analysis may illustrate that there are some aspects of teachers' beliefs that might be affected by teachers' academic 


\section{Macrothink}

degrees more than other components. In addition, the findings from the data analysis also confirmed the previous argument regarding beliefs - namely, that centrally held beliefs are harder to change (Drageset, 2010). The components, which teachers who had bachelor's degrees believed to be the most important in student engagement, are still designated as the most considerable components by those who attained master's degrees. In contrast, connection to prior knowledge, which is the least significant component for teachers who have bachelor's degrees, is believed to be one of the vital components for teachers who have attained master's degrees. This may demonstrate both the difficulties and possibilities of changing teachers' beliefs in the application of their knowledge in mathematics instruction.

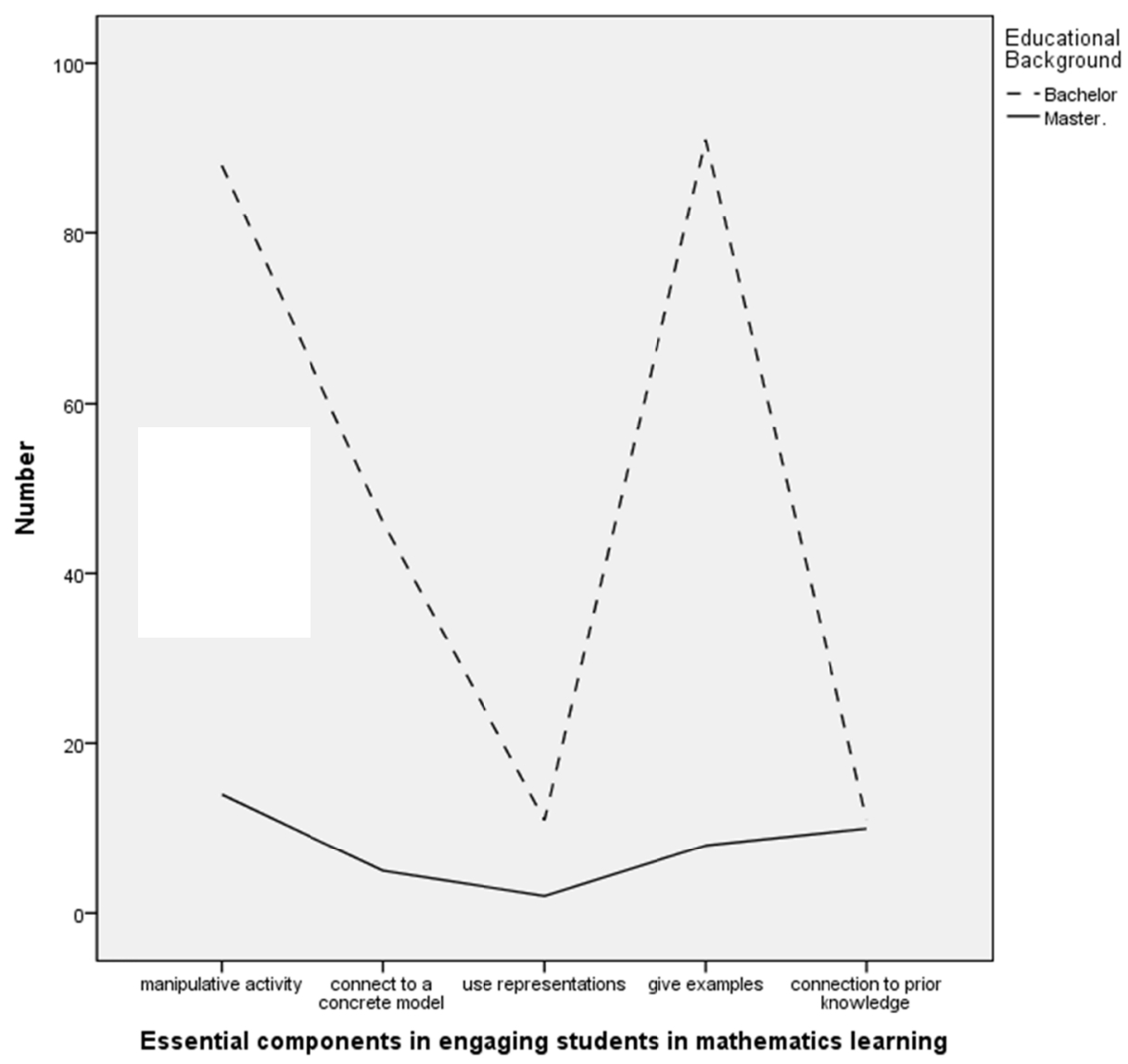

Figure 2. Line graph of essential component for engaging students in mathematics learning

From the analysis of the survey, we found that teachers have certain beliefs regarding the importance they assign to components for building students' mathematics ideas; the differences between the order teachers ranked were statistically significant $(p<0.5)$ except for the relationship between using rules and procedures and using concepts or definitions. A representative view of South Korean elementary teachers' belief structures for building students' mathematics ideas is shown in Figure 3. Figure 3 illustrates that the teachers believed that "connect to prior knowledge" is the most important component, followed by "connect to concrete model"; they considered "use concept or definition" and "use rule and procedures" to be the least important components. 


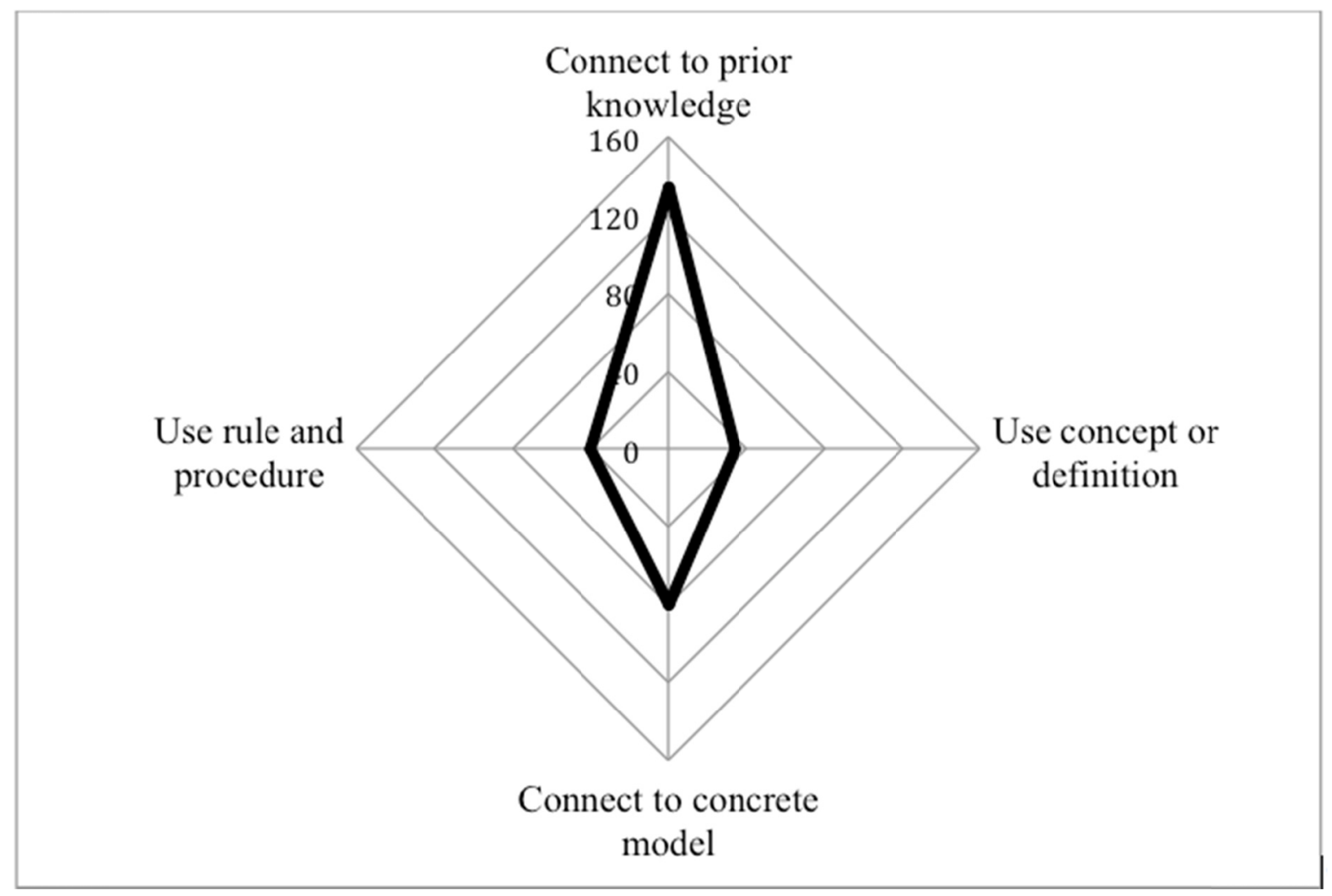

Figure 3. South Korean elementary teachers' belief structures in building students' mathematics ideas

Comparative research between teachers in the United States and China (An et al., 2002) revealed that Chinese teachers tend to consider students' prior knowledge when they help students build new mathematics concepts, while U.S. teachers focus on using concrete models. The researchers also argued that Chinese teachers' approaches might help students to develop their conceptual understanding of mathematics concepts because they focus on the relationships among mathematics concepts. Similar to Chinese teachers, the South Korean elementary teachers also believed that connecting students' prior knowledge is important when teaching new concepts. Although we did not analyze the teachers' teaching practices, we assumed that beliefs play the role of filters when the teachers apply their knowledge from the conceptual framework of this study. Thus, we may assume that these beliefs may affect South Korean elementary teachers' mathematics instruction.

This result is surprising because it is generally known that South Korea's mathematics instruction may focus on developing skills or procedures rather than students' conceptual understanding. South Korea's mathematics curriculum has been dramatically changed since it was first established in 1952. The National Mathematics Curriculum emphasized students' computation skills at the beginning; however, the emphasis has shifted to students' conceptual understanding after seven major revisions (Park, 2010). For example, the major stress of the current National Mathematics Curriculum in South Korea is to support differentiated instruction that highlights students' mathematical thinking in the classroom as 
well as students' understanding of mathematical values (Hwang \& Han, 2012). Mathematical thinking illustrates mathematical communication ability, mathematical reasoning ability, and problem-solving ability in learning (The Ministry of Education of South Korea, 2009). In particular, the National Mathematics Curriculum states the objectives of mathematics education as shown in Table 5.

Table 5. The Objectives of the Mathematics Education (The Ministry of Education, 2009)

Students will learn how to solve mathematics problems that relate to their daily lives and will have positive attitudes toward mathematics by acquiring basic mathematics knowledge and skills and by developing mathematics communication abilities.

A. Students will learn basic concepts and principles of mathematics by observing and manipulating their daily-lives mathematically.

B. Students will learn how to solve daily life problems rationally by developing mathematical thinking and mathematics communication abilities.

C. Students will understand the value of mathematics and have positive attitudes toward mathematics with an interest in mathematics.

According to the development of the National Mathematics Curriculun, the focus in the preservice teacher education program for mathematics teachers also has been moved to students' conceptual understanding in the mathematics classroom (Park, 2010). So far, South Korean students' notable achievements in international mathematics assessments (e.g., PISA, TIMSS) have been considered to be the result of the emphasis on students' proficiency in computation. However, the findings of this study show that South Korean elementary teachers put more emphasis on the connection to prior knowledge than the use rule and procedures. Thus, there needs to be different approaches to understand South Korean teachers' mathematics instruction.

Figure 4 shows that the teachers believed that "use questions or tasks to correct misconceptions" is the most efficient way to address students' misconceptions followed by "draw picture or table," "connect to concrete model," "address students' misconceptions," and "use rule and procedures." A representative view of South Korean elementary teachers' belief structures for addressing students' misconceptions is shown in Figure 4. 


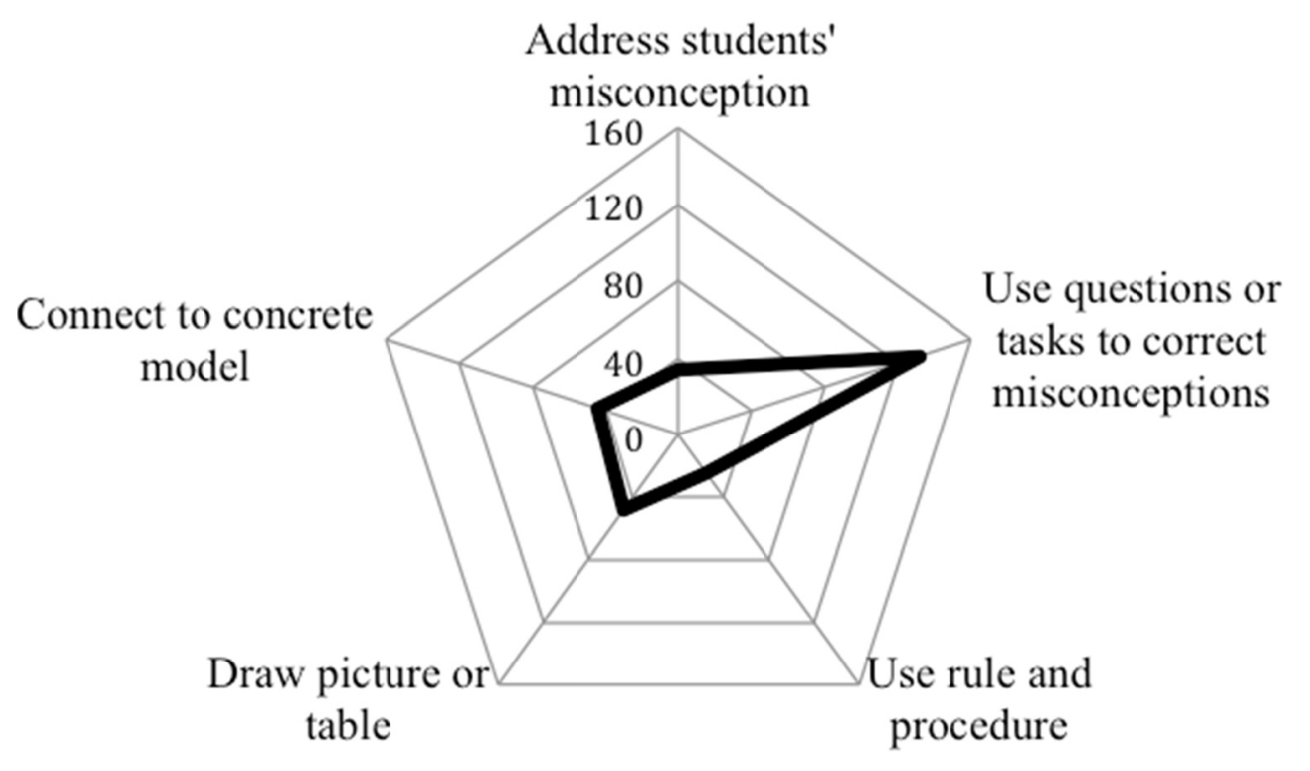

Figure 4. South Korean elementary teachers' belief structures in addressing students' misconceptions about mathematics

An et al. (2002) demonstrated that Chinese elementary teachers prefer to use questions or tasks to correct students' mathematical misconceptions, while the U.S. teachers focused on providing experience with a variety of mathematics models. Similar to Chinese teachers, South Korean elementary teachers believe that it is most effective to use questions or tasks for correcting misconceptions. Various studies reveal that using questions might be an effective way of identifying student mathematical errors while engaging students in the reasoning process (e.g., An et al., 2002; Carroll, 1999).

However, it is a concern that there is one dominant approach toward addressing students' misconceptions. Students may need different instructional strategies based on their various needs for learning mathematics. In addition, each component used to address students' misconceptions has its own strength. For example, the National Council of Teachers of Mathematics [NCTM] (2000) suggested that concrete models might support students in developing abstract mathematics concepts. The results of analysis suggest that both preservice and in-service teacher education programs in South Korea should consider providing food for thought to elementary teachers regarding the use of different strategies to address students' misconceptions.

Figure 5 demonstrates the belief structures of South Korean elementary teachers regarding engaging students in mathematics learning. South Korean elementary teachers believe that "manipulative activity" and "give example" are more effective than "connect to concrete model" and "connection to prior knowledge." The teachers also believe that "use representation" is the least effective component. 


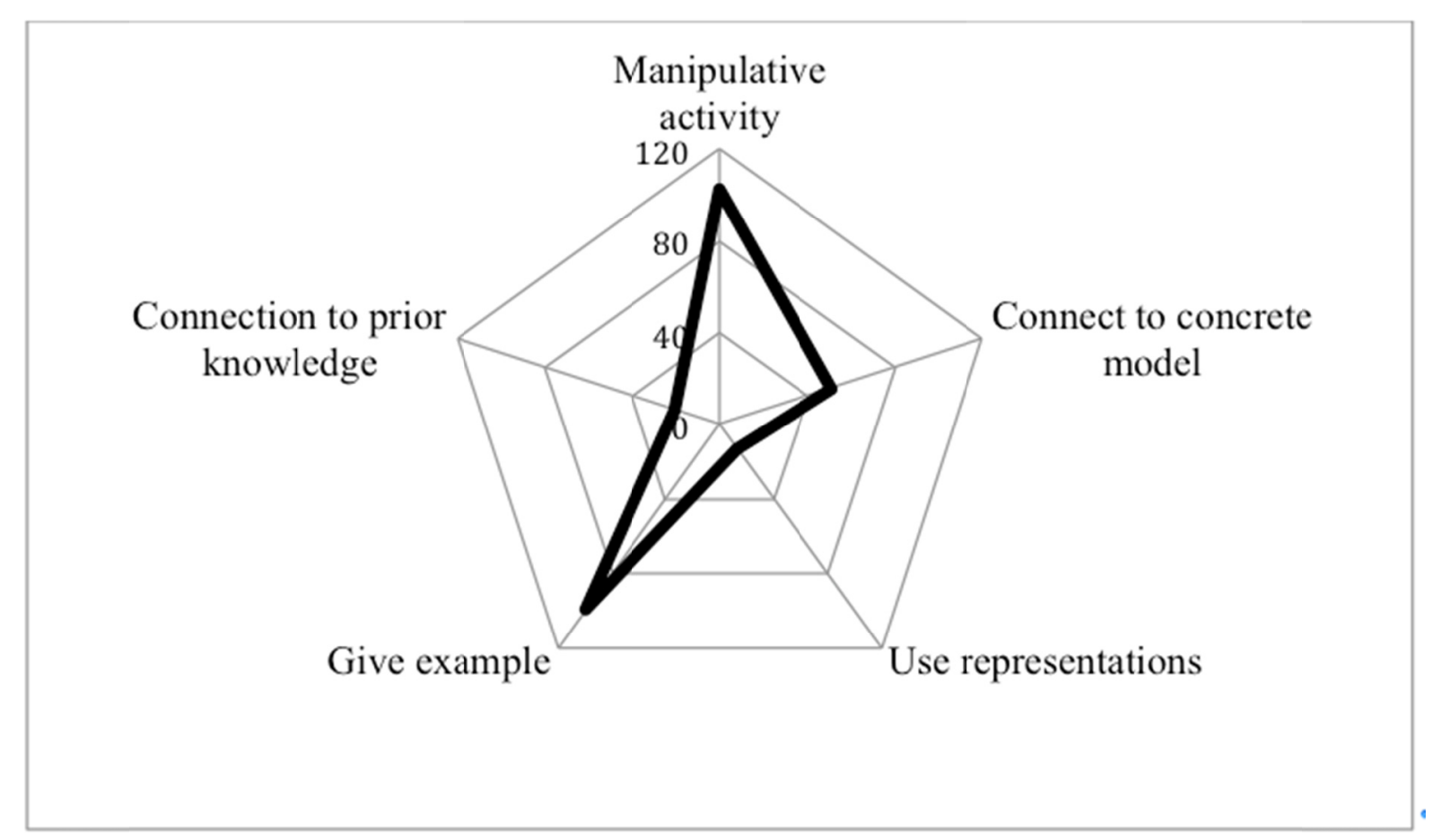

Figure 5. South Korean elementary teachers' belief structures in engaging students in mathematics learning

It is interesting that South Korean elementary teachers believe that "connection to prior knowledge" is not the most significant component in engaging students in mathematics learning, although they consider it to be the most important constituent in building students' mathematical ideas (see Figures 1 and 5). Thus, there needs to be more investigation on how South Korean elementary teachers overcome the gap between what they believe to be significant in students' understanding and in students' engagement in mathematics instruction.

South Korean elementary teachers believe that "use questions or task to help students' progress" is the most effective component in promoting students' thinking about mathematics followed by "provide activities to focus on students' thinking," "use estimation," "draw pictures or tables," and "provide opportunity to think and respond." 


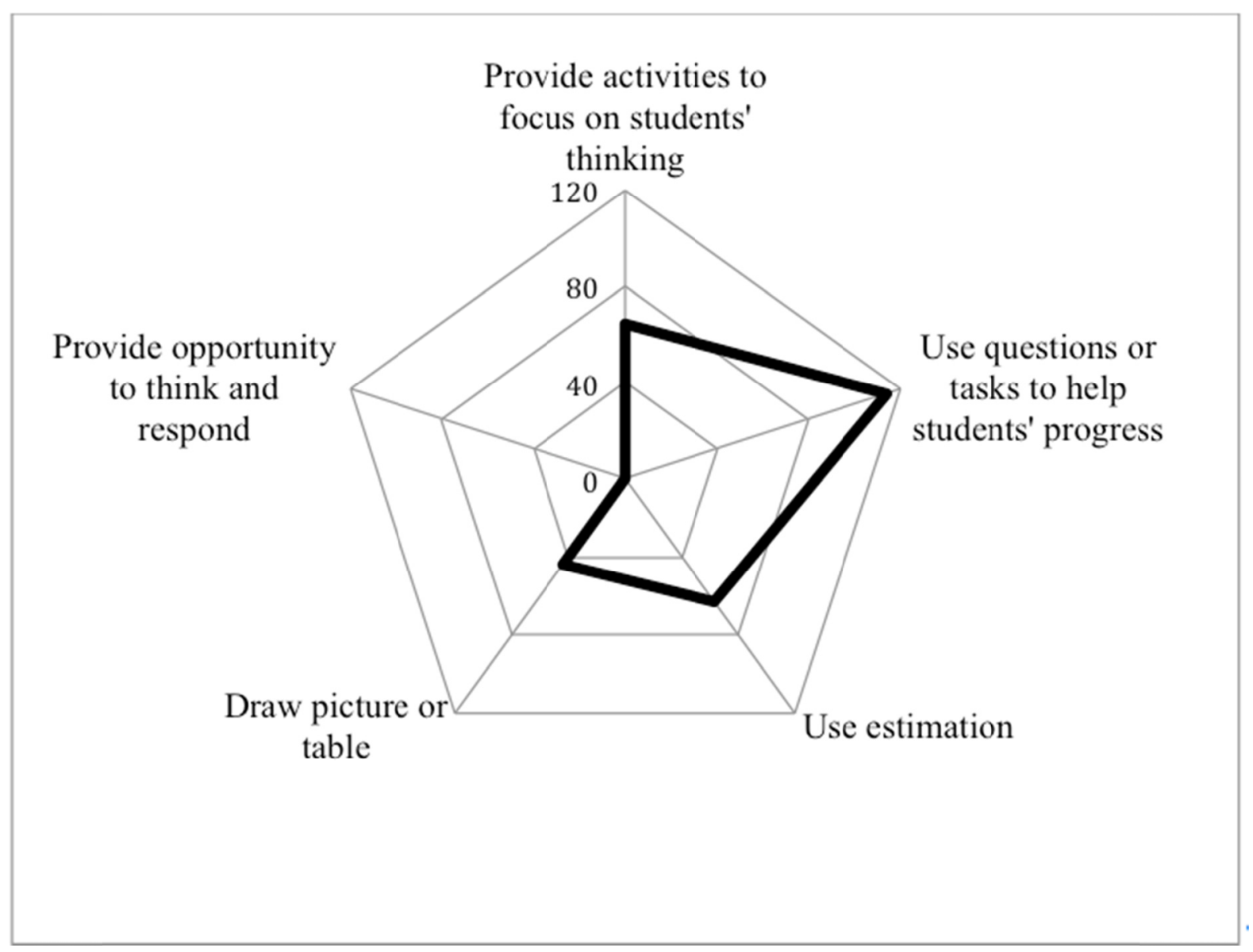

Figure 6. South Korean elementary teachers' belief structures in promoting students' thinking about mathematics

It is noteworthy that none of the teachers chose "provide opportunity to think and respond" as a significant component in the survey. It might not be easy for teachers to wait because they may not observe students' mathematical thinking (Yourstone, Kraye \& Albaum, 2008). However, recent studies suggest that teachers should know how to wait as students develop their own mathematical ideas and thoughts in their mathematics learning (Heinze \& Erhard, 2006; Yourstone et al., 2008). Providing ample time to think about and reflect on their mathematical understanding might be effective for students to build new mathematics concepts based on what they had previously learned (Heinze \& Erhard, 2006). The findings of this study indirectly suggest that there needs to be more discussion about the effects of providing opportunity to think and respond to students in mathematics classrooms in South Korea.

\section{Conclusion}

We identified the belief structures of South Korean elementary teachers in the application of knowledge in mathematics instruction based on the assumption that beliefs play the role of filters when teachers apply their knowledge. From the statistical analysis of the survey data, this study revealed that there are some dominant components in South Korean elementary teachers' belief structures. In addition, some belief components may be affected by a 
teacher's gender and academic degrees.

We acknowledge that the findings of this study should be used as a resource with which to understand South Korean elementary teachers' beliefs in teaching mathematics. We did not analyze how teachers apply their knowledge in their mathematics instruction based on their belief structures as well as the effectiveness of the structure in students' mathematics learning. A teacher may use inappropriate mathematics questions, for example, even though he or she may believe that using questions is an effective method for developing students' mathematical understanding. Thus, further studies should be conducted in this field.

Providing grounds for understanding teachers' belief structures would be meaningful to researchers, policy makers, and directors of teacher education programs. As discussed, there were one or two central components in each category of beliefs. This may indirectly demonstrate equal distribution of teachers in terms of their beliefs in mathematics teaching. South Korean elementary students may have an equal chance to receive similar mathematics instruction regardless of their location because teachers have similar tendencies to apply and use their knowledge in mathematics instruction. At the same time, it is a concern that there is a lack of diversity. The dominant components in each category do not represent that these components might be the most effective strategies for every student in any mathematics classrooms. Thus, there is a need for further studies regarding the effectiveness of various components in students' learning. Furthermore, policy makers and teacher education program directors should consider providing various approaches to mathematics instruction in order to support South Korea's elementary teachers to build balanced belief structures in terms of the application of their knowledge in their mathematics instruction.

This study does not necessarily apply to all elementary teachers in South Korea because the survey only included samples from one city in the country. However, with a centralized education system in South Korea, the results of data analysis might point to the importance of providing representative interpretations of South Korean elementary teachers' belief structures and prompting further understanding of effective mathematics teaching.

\section{References}

An, S., Kulm, G., \& Wu, Z. (2002). The pedagogical content knowledge of middle school, mathematics teachers in China and the U.S. Journal of Mathematics Teacher Education, 7, $145-172$.

Beuhl, M., Alexander, P., \& Murphy, K. (2002). Beliefs about schooled knowledge: Domain general or domain specific? Contemporary Educational Psychology, 27, 415-449. http://dx.doi.org/10.1006/ceps.2001.1103

Carpenter, T. P., \& Lehrer, R. (1999). Teaching and learning with understanding. In E. Fennema \& T. Romberg (Eds.), Mathematics classrooms that promote understanding (pp. 19-32). Mahwah, NJ: Erlbaum.

Carroll, W. M. (1999). Using short questions to develop and assess reasoning. In E. Fennema \& T. Romberg (Eds.), Mathematics classrooms that promote understanding (pp. 19-32). Mahwah, 
NJ: Erlbaum.

Casey, M. B., Nuttall, R. L., \& Pezaris, E. (2001). Spatial-mechanical reasoning skills versus mathematics self-confidence as mediators of gender differences on mathematics subtests using cross-national gender-based items. Journal for Research in Mathematics Education, 32(1), 28-57. http://dx.doi.org/10.2307/749620

Cooney, T. (2003). Mathematics teacher education in rural communities: Developing a foundation for action. Paper presented at the ACCLAIM Research Symposium, McArthur, OH.

Cooney, T., Shealy, B., \& Arvold, B. (1998). Conceptualizing belief structures of preservice secondary mathematics teachers. Journal of Research in Mathematics Education, 29(3), 306-333. http://dx.doi.org/10.2307/749792

Cross, D. I. (2009). Alignment, cohesion and change: Examining mathematics teachers' belief structure and their influence on instructional practice. Journal of Mathematics Teacher Education, 12(5), 325-346. http://dx.doi.org/10.1007/s10857-009-9120-5

Drageset, O.G. (2010). The interplay between the beliefs and the knowledge of mathematics teachers. Mathematics Teacher Education and Development, 12(1), 30-49.

Ernest, P. (1988). The impact of beliefs on the teaching of mathematics. Paper presented at the ICME IV, Budapest, Hungary.

Fennema, E., Carpenter, T. P., Jacobs, V. R., Franke, M. L., \& Levi, L. W. (1998). A longitudinal study of gender differences in young children's mathematical thinking. Educational Researcher, 27(5), 6-11. http://dx.doi.org/10.2307/1176733

Goldin, G., Rosken, B., \& Torner, G. (2009). Beliefs- No longer a hidden variable in mathematical teaching and learning processes. In J. Maass, \& Schloglmann (Eds.), Beliefs and Attitudes in Mathematics Education (pp.1-18). Rotterdam, The Netherlands: Sense Publication.

Hwang, H. J., \& Han, H. S. (2012). Current National Mathematics Curriculum. In Kim, J., Han, I, Park, M., \& Lee, J. K. (Ed.), Mathematics Education in Korea (pp. 21-42) World Scientific Publishing Co. http://dx.doi.org/10.1142/9789814405867_0002

Haser, C., \& Doğan, O., (2009). Alignment, cohesion, and change: Examining mathematics teachers' belief structures and their influence on instructional practices (Report). Journal of Mathematics Teacher Education, 12(5), 325. http://dx.doi.org/10.1007/s10857-009-9120-5

Heinze, A., \& Erhard, M. (2006). How much time do students have to think about teacher questions? An investigation of the quick succession of teacher questions and student responses in the German mathematics classroom. ZDM, 38(5), 388-398. http://dx.doi.org/10.1007/BF02652800

Kilpatrick, J., Swafford, J., \& Findell, B. (Eds.). (2001). Adding It Up: Helping Children Learn Mathematics. Washington: National Academy Press.

Kelly, K., Clark, B., Brown, V., \& Sitzia, J. (2003). Good practice in the conduct and reporting 
of survey research. International Journal for Quality in Health Care, 15, 261-266. http://dx.doi.org/10.1093/intqhe/mzg031

Kraemer, K. L. (1991). Introduction. Paper presented at the Information System Research Challenge: Survey Research Methods.

Leatham, K. R. (2006). Viewing mathematics teachers' beliefs as sensible systems. Journal of Mathematics Teacher Education, 9, 91-102. http://dx.doi.org/10.1007/s10857-006-9006-8

Lindblom-Ylanne, S., Trigwell, K., Nevgi, A., \& Ashwin, P. (2006). How approaches to teaching are affected by discipline and teaching context. Studies in Higher Education, 31(3), 285-298. http://dx.doi.org/10.1080/03075070600680539

National Council of Teachers of Mathematics (NCTM). (2000). Principles and standards for school mathematics. Reston, VA: Author.

Park, K. (2010). Mathematics teacher education in Korea. In Koon, F., Leung, S., \& Li, Y. (Eds.), Reforms and issues in school mathematics in East Asia: Sharing and understanding mathematics education policies and practices (pp. 181-196). Chesapeake, VA: AACE.

Pajares, M. F. (1992). Teachers' beliefs and educational research: cleaning up a messy construct. Review of Educational Research, 62(3), 307-332. http://dx.doi.org/10.3102/00346543062 003307

Philipp, R. (2007). Mathematics teachers' beliefs and affect. In F. K. Lester (Ed.), Second handbook of research on mathematics teaching and learning (pp. 257-315). Charlotte, NC: Information Age Publishing.

Philipp, R. A., Ambrose, R., Lamb, L. L., Sowder, J. T., Schappelle, B. P., Sowder, L., Thanheiser, E., \& Chauvot, J. (2007). Effect of early field experiences on the mathematical content knowledge and beliefs of prospective elementary school teachers: An experimental study. Journal for Research in Mathematics Education, 38(5), 438-476.

Rimm-Kaufman, S., \& Sawyer, B. (2004). Primary-grade teachers' self-efficacy beliefs, attitudes toward teaching, and discipline and teaching practice priorities in relation to the responsive classroom approach. The Elementary School Journal, 104(2), 321-341. http://dx.doi.org/10.1086/499756

Shavelson, R. J. (1996). Statistical reasoning for the behavioral sciences (3rd ed.). Stanford University: Allyn and Bacon.

Shulman, L. (1987). Knowledge and teaching: Foundations of the new reform. Harvard Educational Review, 57(1), 1-22.

Torff, B. (2005). Developmental changes in teachers' beliefs about critical thinking activities. Journal of Educational Psychology, 97(1), 13-22. http://dx.doi.org/10.1037/0022-0663. 97.1 .13

Torff, B., \& Warburton, E. C. (2005). Assessment of teachers' beliefs about classroom use for critical thinking activities. Educational and Psychological Measurement, 65, 155-179. 
http://dx.doi.org/10.1177/0013164404267281

The Ministry of Education of South Korea. (2009). The National Mathematics Curriculum. Retrieved September 4, 2013, from http://cutis.mest.go.kr/main.jsp?.gCd=S02\&siteCms $\mathrm{Cd}=\mathrm{CM} 0001$

The Ministry of Education of South Korea. (2012). Statistical analysis of education in South Korea. Retrieved September 7, 2013, from http://cesi.kedi.re.kr/

Thompson, A. (1992). Teachers' beliefs and conceptions: A synthesis of research. In D. Grouws (Ed.), Handbook of research on mathematics teaching and learning (pp. 127-146). New York, NY: Macmillan.

Wilson, M., \& Cooney, T. (2002). Mathematics teacher change and development. The role of beliefs. In G. C. Leder, E. Pehkonen \& G. Törner (Eds.), Beliefs: A hidden variable in mathematics education? (pp. 127-147). Dordrecht, Netherlands: Kluwer Academic Publishers.

Yourstone, S. A., Kraye, H. S., \& Albaum, G. (2008). Classroom questioning with immediate electronic response: Do clickers improve learning? Decision Sciences Journal of Innovative Education, 6(1), 75-88. http://dx.doi.org/10.1111/j.1540-4609.2007.00166.x

\section{Copyright Disclaimer}

Copyright reserved by the authors.

This article is an open-access article distributed under the terms and conditions of the Creative Commons Attribution license (http://creativecommons.org/licenses/by/3.0/). 